\title{
ANALISIS FAKTOR-FAKTOR YANG BERPENGARUH TERHADAP KETEPATAN WAKTU PENYAMPAIAN LAPORAN KEUANGAN PADA PERUSAHAAN YANG LISTING DI BURSA EFEK INDONESIA
}

\author{
Afriyeni, Doni Marlius \\ Akademi Keuangan dan Perbankan Padang \\ afriyeni@akbpstie.ac.id
}

\begin{abstract}
This research is aimed to analyzes the factors that influence of timely submission of financial statements of listed companies in Indonesia. Factors tested in this study are profitability, liquidity, financial leverage, firm size, complexity of companies operations, public ownership, accounting firms reputation, and auditors opinion as independent variable whereas timely submission as dependen variable. The study sample consisted of 296 companies listed on the Indonesian stock exchange (IDX) and submit financial reports to Bapepem in the period 2009 - 2011. Data used in this study is secondary data and the selection of the sample by using purposive sampling. Analysis tool used is the logistic regression analysis at a significance level 5\%. Hypothesis testing results show that profitabilty, firm size, complexity of companies operations, public ownership, and accounting firms reputation significantly influence the timeliness of financial statement however, no evidence that liquidity, finacial leverage and auditors opinion influence the timeliness of financial statement. From the eight variables studied only five variables that significantly affect the timeliness of financial statement namely profitability, firm size, complexity of companies operations, public ownership, and accounting firms reputation.
\end{abstract}

Keyword : timeliness, financial statement, profitability, firm size, complexity of companies operations, public ownership, and accounting firms reputation.

\section{PENDAHULUAN}

Laporan keuangan merupakan informasi mengenai kinerja keuangan perusahaan selama satu peride yang dapat membantu manajemen serta stakeholder dalam mengambil keputusan sesuai dengan kepentinganya. Sejalan dengan meningkatnya kompleksitas kegiatan operasi bisnis dan pertumbuhan investasi pada saat ini, para investor sebagai salah satu stakeholder memerlukan lebih banyak informasi yang relevan dan tepat waktu. Kebutuhan akan ketepatan waktu pelaporan keuangan secara jelas telah disebutkan dalam kerangka dasar 
penyusunan penyajian laporan keuangan bahwa ketepatan waktu merupakan salah satu karakteristik yang harus dipenuhi agar laporan keuangan yang disajikan relevan untuk pembuat keputusan. Semakin cepat informasi diungkapkan, maka akan semakin relevan informasi tersebut bagi para pengguna laporan keuangan. Pengguna laporan keuangan sangat membutuhkan informasi yang tepat waktu untuk memungkinkan mereka dapat dengan segera melakukan analisis dan membuat keputusan tentang modal yang sudah atau akan diinvestasikan pada perusahaan.

Setiap perusahaan yang go public memiliki kewajiban untuk menyampaikan laporan keuangan yang disusun sesuai dengan standar akuntansi keuangan dan telah diaudit tepat waktu. Tuntutan akan kepatuhan terhadap ketepatan waktu dalam penyampaian laporan keuangan publik di Indonesia telah diatur dalam UU No. 8 tahun 1995 tentang Pasar Modal. Dalam peraturan ini disebutkan bahwa emiten dan perusahaan public wajib menyampaikan laporan keuangan tahunan yang telah diaudit oleh akuntan independen, selambat- lambatnya pada akhir bulan keempat (120 hari) setelah tanggal laporan keuangan perusahaan. Kemudian Bapepam memperketat peraturan dengan dikeluarkannya Keputusan Ketua Bapepam No. 36/PM/2003 tentang Kewajiban Penyampaian Laporan Keuangan Berkala.

Keluarnya peraturan tersebut merupakan cerminan bahwa pihak pembuat peraturan (regulator) cukup serius menanggapi kasus ketidakpatuhan dalam penyampaian laporan keuangan. Menurut pengumuman Bursa Efek Indonesia (Peng-LK-00266/BEI.PSR/06-2009, PengLK00289/BEI. PSJ/06-2009) terdapat 13 (tiga belas) Perusahaan Tercatat yang hingga tanggal 29 Mei 2009, belum menyampaikan Laporan Keuangan Auditan untuk Periode yang Berakhir per 31 Desember 2008. Sehingga, mengacu pada ketentuan bursa, Bursa Efek Indonesia (BEI) telah memberikan Peringatan Tertulis III dan denda sebesar Rp 150.000.000,- kepada 13 (tiga belas) perusahaan tersebut.

Berdasarkan fakta tersebut, maka perlu diketahui faktor-faktor apa saja yang dapat mempengaruhi ketepatan waktu penyampaian laporan keuangan perusahaan kepada publik. Penelitian-penelitian sebelumnya telah menemukan bukti empiris bahwa keterlambatan penyampaian laporan keuangan dipengaruhi oleh beberapa faktor seperti: berita buruk perusahaan, seperti keterlambatan pelaporan dihubungkan dengan kesulitan keuangan (financial distress) perusahaan, kerugian perusahaan, pendapat selain unqualified opinion oleh auditor, dan keterlambatan audit. Selanjutnya faktor kinerja perusahaan yang menunjukkan bahwa return on equity (ROE) dan ukuran perusahaan berpengaruh signifikan terhadap kecepatan perusahaan dalam pelaporan keuangan. Faktor kinerja keuangan lainnya seperti debt to equity ratio dan profitabilitas tidak mempengaruhi ketepatan waktu pelaporan keuangan.

Dari hasil penelitian yang telah dilakukan menunjukkan bahwa terdapat banyak faktor yang berpengaruh terhadap ketepatan waktu penyampaian laporan keuangan, namun demikian juga dapat diketahui bahwa terdapat ketidakkonsistenan dalam hasil-hasil penelitian yang telah dilakukan. Oleh karena itu penelitian ini akan mengidentifikasi faktor-faktor profitabilitas, likuiditas, leverage keuangan, ukuran perusahaan, kompleksitas operasi perusahaan, 
kepemilikan publik, reputasi kantor akuntan publik (KAP), dan opini auditor.

\section{TINJAUAN LITERATUR \\ Teori Kepatuhan (Compliance Theory)}

Tuntutan akan kepatuhan terhadap ketepatan waktu dalam penyampaian laporan keuangan tahunan perusahaan public di Indonesia telah diatur dalam Undang-Undang No. 8 Tahun 1995 tentang Pasar Modal, dan selanjutnya diatur dalam Peraturan Bapepam Nomor X.K.2, Lampiran Keputusan Ketua Bapepam Nomor: KEP-36/PM/2003 tentang Kewajiban Penyampaian Laporan Keuangan Berkala. Peraturan-peraturan tersebut secara hukum mengisyaratkan adanya kepatuhan setiap perilaku individu maupun organisasi (perusahaan publik) yang terlibat di pasar modal Indonesia untuk menyampaikan laporan keuangan tahunan perusahaan secara tepat waktu kepada Bapepam. Hal tersebut sesuai dengan teori kepatuhan (compliance theory).

Teori kepatuhan telah diteliti dalam ilmu-ilmu sosial khususnya di bidang psikologi dan sosiologi yang lebih menekankan pada pentingnya proses sosialisasi dalam mempengaruhi perilaku kepatuhan seorang individu. Menurut Tyler (dalam Saleh dan Susilowati, 2004) terdapat dua perspektif dasar mengenai kepatuhan hukum yaitu instrumental dan normatif. Perspektif instrumental mengasumsikan individu secara utuh didorong oleh kepentingan pribadi dan tanggapan-tanggapan terhadap perubahan insentif, dan penalty yang berhubungan dengan perilaku. Perspektif normative berhubungan dengan apa yang orang anggap sebagai moral dan berlawanan dengan kepentingan pribadi mereka.

Teori kepatuhan dapat mendorong seseorang untuk lebih mematuhi peraturan yang berlaku, sama halnya dengan perusahaan yang berusaha untuk menyampaikan laporan keuangan secara tepat waktu karena selain merupakan suatu kewajiban perusahaan untuk menyampaikan laporan keuangan tepat waktu, juga akan sangat bermanfaat bagi para pengguna laporan keuangan.

\section{Teori Keagenan (Agency Theory)}

Teori keagenan adalah teori yang menjelaskan hubungan antara agen sebagai pihak yang mengelola perusahaan dan principal sebagai pihak pemilik, keduanya terikat dalam sebuah kontrak. Pemilik atau prinsipal adalah pihak yang melakukan evaluasi terhadap informasi dan agen adalah sebagai pihak yang menjalankan kegiatan manajemen dan mengambil keputusan (Jensen dan Meckling, 1976).

Teori keagenan juga mengimplikasikan terdapat asimetri informasi antara manajer sebagai pihak agen dan pemilik sebagai prinsipal. Asimetri informasi timbul ketika manajer lebih mengetahui informasi internal dan prospek perusahaan pada masa yang akan datang dibandingkan dengan informasi yang diperoleh prinsipal, sehingga dalam kaitannya dengan hal tersebut, (Kim dan Verrechia dalam Kadir, 2008) menyatakan bahwa laporan keuangan yang disampaikan dengan segera atau tepat waktu akan dapat mengurangi asimetri informasi tersebut.

\section{Laporan Keuangan}

Menurut Baridwan (1997) laporan keuangan merupakan ringkasan dari proses pencatatan, yang merupakan ringkasan dari transaksi keuangan yang terjadi 
selama tahun buku yang bersangkutan. Laporan keuangan ini dibuat oleh pihak manajemen dengan tujuan untuk mempertanggungjawabkan tugas yang dibebankan kepadanya oleh pemilik perusahaan.

Menurut PSAK No. 1 (IAI, 2007) tujuan laporan keuangan adalah memberikan informasi tentang posisi keuangan, kinerja, dan arus kas perusahaan yang bermanfaat bagi sebagian besar kalangan pengguna laporan dalam rangka membuat keputusan-keputusan ekonomi serta menunjukkan pertanggungjawaban manajemen atas penggunaan sumber-sumber daya yang dipercayakan kepada mereka. Dalam rangka mencapai tujuan tersebut, suatu laporan keuangan menyajikan informasi mengenai perusahaan yang meliputi: (1) aset; 2) kewajiban; (3) ekuitas; (4) pendapatan dan beban termasuk keuntungan dan kerugian; dan (5) arus kas.

Financial Accounting Standards Board (Hendriksen dan Van Breda, 2000, h.136) meringkaskan bahwa tujuan-tujuan pelaporan keuangan adalah menyediakan informasi yang berguna bagi investor dan kreditor dan pemakai lain yang sekarang dan yang potensial mengambil keputusan rasional untuk investasi, kredit dan yang serupa, menyediakan informasi mengenai sumber daya ekonomi dari satuan usaha, tuntutan terhadap sumberdaya tersebut dan pengaruh transaksi, kejadian, dan situasi yang mengubah sumberdaya dan tuntutannya pada sumberdaya tersebut.

Berkaitan dengan perusahaan yang terdaftar di Bursa Efek Indonesia, persyaratan ketepatan waktu merupakan suatu keharusan, karena perusahaan yang tidak tepat waktu menyampaikan laporan keuangannya akan dikenakan sanksi administrasi dan denda sesuai dengan ketentuan pasal 63 huruf e Peraturan Pemerintah Nomor 45 Tahun 1995 tentang Penyelenggaraan Kegiatan di Bidang Pasar Modal yang menyatakan bahwa "Emiten yang pernyataan Pendaftarannya telah menjadi efektif, dikenakan sanksi denda $\mathrm{Rp} 1.000 .000$ (satu juta rupiah) atas setiap hari keterlambatan penyampaian laporan dengan ketentuan jumlah keseluruhan denda paling banyak Rp 500.000.000 (lima ratus juta rupiah)."

Pasar modal di Indonesia memandang keterlambatan tersebut sebagai pelanggaran terhadap prinsip keterbukaan informasi di pasar modal. Ketepatan waktu juga turut mendukung kinerja pasar yang efisien dan cepat serta mengurangi kebocoran dan rumor di pasar saham (Ukago, 2004).

\section{Ketepatan Waktu (Timeliness)}

Salah satu cara untuk mengukur transparansi dan kualitas pelaporan keuangan adalah ketepatan waktu. Rentang waktu antara tanggal laporan keuangan perusahaan dan tanggal ketika informasi keuangan diumumkan ke public berhubungan dengan kualitas informasi keuangan yang dilaporkan (McGee, 2007). Hendriksen dan Breda (2000, h.145) menyatakan bahwa informasi tidak dapat relevan jika tidak tepat waktu, yaitu hal itu harus tersedia bagi pengambil keputusan sebelum kehilangan kapasitasnya untuk mempengaruhi keputusan. Ketepatan waktu tidak menjamin relevansinya, tetapi relevansi tidaklah mungkin tanpa ketepatan waktu. Oleh karena itu, ketepatan waktu adalah batasan penting pada publikasi laporan keuangan.

Sesuai dengan peraturan X.K.2 yang diterbitkan Bapepam, maka penyampaian laporan keuangan tahunan yang telah diaudit dikatakan tepat waktu 
apabila diserahkan sebelum atau paling lambat pada akhir bulan ketiga setelah tanggal laporan keuangan tahunan perusahaan publik tersebut. Keterlambatan penyampaian laporan keuangan bisa berakibat buruk bagi perusahaan baik secara langsung maupun tidak langsung. Secara tidak langsung, para investor mungkin menanggapi keterlambatan tersebut sebagai sinyal yang buruk bagi perusahaan, sebagai contoh di pasar modal Indonesia pada tahun 2009, perusahaan-perusahaan public yang melanggar prinsip keterbukaan informasi dengan tidak menyampaikan laporan keuangan tahunan tepat waktu telah dikenakan sanksi administrasi dan denda.

\section{Penelitian Terdahulu}

Penelitian mengenai faktor-faktor yang mempengaruhi ketepatan waktu penyampaian laporan keuangan perusahaan publik ini, telah banyak dilakukan dan berkembang baik di Indonesia maupun di negara-negara lain. Dyer dan McHugh (dalam Oktorina dan Suharli, 2005) meneliti profil ketepatan waktu pelaporan dan normalitas keterlambatan dengan menggunakan 120 perusahaan di Australia periode 1965-1971. Mereka menguji variabel ukuran perusahaan, tanggal berakhirnya tahun buku dan profitability. Hasil penelitian mereka menunjukkan bahwa ukuran perusahaan dan tanggal berakhirnya tahun buku berpengaruh dengan ketepatan waktu penyampaian laporan keuangan, sedangkan profitabilitas tidak signifikan mempengaruhi ketepatan waktu pelaporan.

Selain itu, Owusu-Ansah (2000) meneliti ketepatan waktu pelaporan keuangan dari 47 perusahaan di Zimbabwe, yang menguji variable ukuran perusahaan, profitabilitas, gearing (kecepatan), item luar biasa, bulan dari akhir tahun keuangan, kompleksitas operasi perusahaan dan umur perusahaan. Hasil penelitiannya menemukan bukti empiris bahwa ukuran perusahaan, kompleksitas operasi perusahaan, umur perusahaan dan bulan dari akhir tahun keuangan berpengaruh terhadap audit reporting lead time. Kemudian ukuran perusahaan, profitabilitas, umur perusahaan dan audit reporting lead time mempengaruhi kecepatan perusahaan dalam mengumumkan pendapatan awalnya, tetapi hanya ukuran perusahaan yang mempengaruhi ketepatan waktu penyampaian laporan keuangan akhir tahun yang telah diaudit.

Sedangkan Dogan, et. Al (2007) meneliti tentang hubungan antara ketepatan waktu pelaporan keuangan dengan kinerja perusahaan. Hasil penelitiannya menunjukkan bahwa return on equity (ROE), change net return (CNR) dan ukuran perusahaan berpengaruh signifikan terhadap kecepatan perusahaan dalam pelaporan keuangan. Sedangkan change in financial risk (CFR), free float rate (FFR) dan jenis industri tidak berpengaruh signifikan terhadap kecepatan perusahaan dalam pelaporan keuangan, serta rasio transaksi memiliki hubungan yang terbalik dengan ketepatan waktu pelaporan keuangan.

Di Indonesia, Respati (2001) meneliti faktor-faktor yang berpengaruh terhadap ketepatan waktu pelaporan keuangan di Bursa Efek Jakarta (BEJ). Penelitian ini menguji variable penelitian: profitability, outsider ownership concentration, debt to equity, ukuran perusahaan, dan insider ownership concentration. Hasil penelitiannya menemukan bukti empiris bahwa faktor profitability, outsider ownership concentration, signifikan berpengaruh terhadap ketepatan waktu pelaporan keuangan. Sedangkan debt to equity, ukuran 
perusahaan dan insider ownership concentration, tidak signifikan berpengaruh terhadap ketepatan waktu pelaporan keuangan perusahaan.

Selain itu, Shaleh dan Susilowati (2004) melakukan penelitian mengenai ketepatan waktu pelaporan keuangan pelaporan keuangan perusahaan manufaktur di Bursa Efek Jakarta (BEJ), dengan menggunakan variabel penelitian: rasio gearing, profitabilitas, ukuran perusahaan, umur perusahaan, item-item luar biasa dan/atau kontijensi, serta struktur kepemilikan. Hasil penelitian mereka menunjukkan bahwa rasio gearing, profitabilitas, ukuran perusahaan, umur perusahaan dan struktur kepemilikan tidak signifikan berpengaruh terhadap ketepatan waktu pelaporan keuangan. Sedangkan item-item luar biasa dan/atau kontijensi berpengaruh signifikan dan mempunyai hubungan sesuai dengan hipotesis yang ada, yaitu negatif.

Lebih lanjut, Oktorina dan Suharli (2005) meneliti faktor-faktor penentu kepatuhan ketepatan waktu pelaporan keuangan, hasil penelitiannya menemukan bukti empiris bahwa debt to equity ratio dan profitabilitas tidak mempengaruhi ketepatan waktu pelaporan keuangan, sedangkan ukuran perusahaan, struktur kepemilikan perusahaan, dan kantor akuntan besar mempengaruhi ketepatan waktu pelaporan keuangan. Meskipun menunjukkan hasil yang signifikan, namun hubungan antara ukuran perusahaan dengan ketepatan waktu ialah tidak searah.

Hilmi dan Ali (2008) melakukan penelitian terhadap faktor-faktor yang mempengaruhi ketepatan waktu penyampaian laporan keuangan. Hasil penelitian mereka menunjukkan bahwa profitabilitas, likuiditas, kepemilikan publik dan reputasi kantor akuntan public (KAP) berpengaruh signifikan terhadap ketepatan waktu penyampaian laporan keuangan, sedangkan leverage keuangan, ukuran perusahaan dan opini akuntan publik tidak signifikan berpengaruh terhadap ketepatan waktu penyampaian laporan keuangan.

\section{Kerangka Pemikiran}

Berdasarkan pada telaah pustaka dan hasil penelitian terdahulu, maka dapat disusun kerangka pemikiran yang menggambarkan hubungan antara profitabilitas, likuiditas, leverage keuangan, ukuran perusahaan, kompleksitas operasi perusahaan, kepemilikan publik, reputasi kantor akuntan publik (KAP), opini auditor dan ketepatan waktu penyampaian laporan keuangan sebagai berikut:

\section{Gambar 1. Hipotesis}

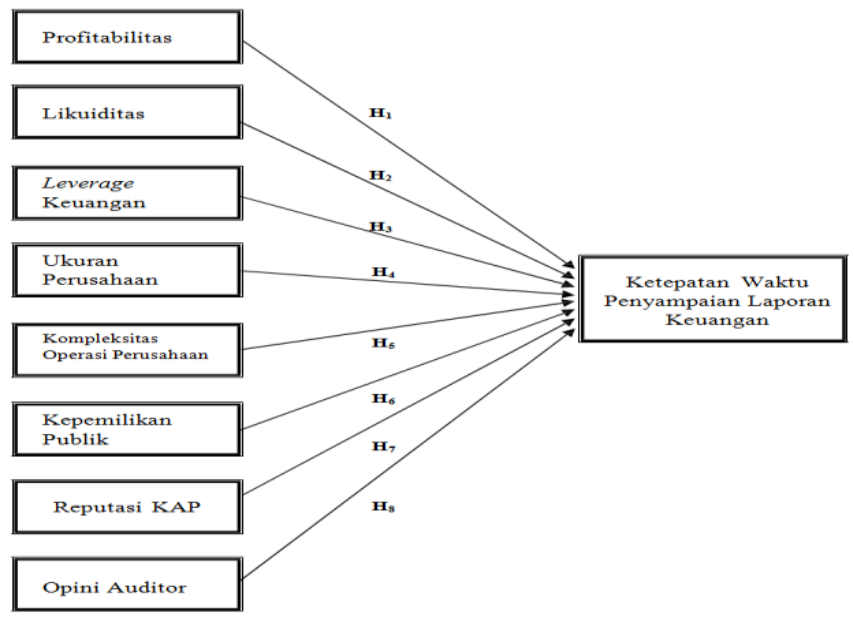




\section{Hipotesis Penelitian}

H1: Profitabilitas berpengaruh terhadap ketepatan waktu penyampaian laporan keuangan.

$\mathrm{H} 2$ : Likuiditas berpengaruh terhadap ketepatan waktu penyampaian laporan keuangan.

H3 : Leverage keuangan berpengaruh terhadap ketepatan waktu penyampaian laporan keuangan.

H4 : Ukuran perusahaan berpengaruh terhadap ketepatan waktu penyampaian laporan keuangan.

H5: Kompleksitas operasi perusahaan berpengaruh terhadap ketepatan waktu penyampaian laporan keuangan.

H6: Kepemilikan publik berpengaruh terhadap ketepatan waktu penyampaian laporan keuangan.

H7: Reputasi kantor akuntan public (KAP) berpengaruh terhadap ketepatan waktu penyampaian laporan keuangan.

H8: Opini auditor berpengaruh terhadap ketepatan waktu penyampaian laporan keuangan.

\section{Definisi Operasional Variabel}

\section{Variabel Dependen}

Ketepatan waktu penyampaian laporan keuangan sebagai variabel dependen diukur berdasarkan tanggal penyampaian laporan keuangan tahunan auditan ke Bapepam. Perusahaan dikategorikan tepat waktu jika laporan keuangan disampaikan selambat-lambatnya pada tanggal 31 Maret, sedangkan perusahaan yang terlambat adalah perusahaan yang menyampaikan laporan keuangan setelah tanggal 31 Maret. Variabel ini diukur dengan menggunakan variable dummy dengan kategorinya adalah bagi perusahaan yang tidak tepat waktu (terlambat) masuk kategori 1 dan perusahaan yang tepat waktu masuk kategori 0 .

\section{Variabel Independen}

\section{Profitabilitas}

Profitabilitas merupakan salah satu indikator keberhasilan perusahaan (efektifitas manajemen) untuk dapat menghasilkan laba sehingga semakin tinggi profitabilitas, maka semakin tinggi kemampuan perusahaan untuk menghasilkan laba bagi perusahaannya. Profitabilitas diproksikan dengan return on assets (ROA). ROA merupakan rasio yang terpenting di dalam rasio profitabilitas yang ada (Ang, 1997). Rasio ini bisa dihitung sebagai berikut:

\section{Likuiditas}

$$
\text { Return On Assets }(\mathrm{ROA})=\frac{\text { Laba Bersih }}{\text { Total Asset }}
$$

Merupakan kemampuan perusahaan dalam melunasi kewajiban jangka pendeknya saat jatuh tempo. Variabel ini diproksikan dengan current ratio (CR). Current Ratio mengukur kemampuan perusahaan memenuhi kewajiban jangka pendeknya dengan menggunakan aset lancarnya. Rasio ini dapat dihitung sebagai berikut:

$$
\text { Current Ratio }(\mathrm{CR})=\frac{\text { Aset Lancar }}{\text { Kewajiban Lancar }}
$$




\section{Leverage Keuangan}

Leverage keuangan merupakan cerminan dari struktur modal perusahaan. Rasio leverage merupakan suatu rasio pengungkit yang menggunakan uang pinjaman (debt) untuk memperoleh keuntungan (Ang, 1997). Variabel ini diproyeksikan dengan debt to equity ratio (DER). Rasio ini menggambarkan perbandingan kewajiban dan ekuitas dalam pendanaan perusahaan dan menunjukkan kemampuan modal sendiri perusahaan tersebut untuk memenuhi seluruh kewajibannya.

\section{Ukuran Perusahaan}

$$
\text { Debt to Equity Ratio }(\mathrm{DER})=\frac{\text { Total Kewajiban }}{\text { Total Ekuitas }}
$$

Ukuran perusahaan dapat dinilai dari beberapa segi. Besar kecilnya ukuran perusahaan dapat didasarkan pada total nilai aset, total penjualan, kapitalisasi pasar, jumlah tenaga kerja dan sebagainya. Semakin besar nilai item-item tersebut maka semakin besar pula ukuran perusahaan itu. Pada penelitian ini, ukuran perusahaan diproksikan dengan menggunakan Ln total asset. Penggunaan natural log (Ln) dalam penelitian ini dimaksudkan untuk mengurangi fluktuasi data yang berlebih.

\section{Kompleksitas Operasi Perusahaan}

Kompleksitas operasi dalam penelitian ini ditentukan dengan ada tidaknya anak perusahaan. Pengukurannya menggunakan variable dummy. Dimana kategori 1 untuk perusahaan yang memiliki anak perusahaan dan kategori 0 untuk perusahaan yang tidak memiliki anak perusahaan.

\section{Kepemilikan Publik}

Kepemilikan publik adalah kepemilikan masyarakat umum (bukan institusi yang signifikan) terhadap saham perusahaan publik. Variabel ini diukur dengan melihat dari berapa besar saham yang dimiliki oleh publik pada perusahaan go public yang terdaftar di Bursa Efek Indonesia (BEI). Pada Indonesian Capital Market Directory (ICMD) telah dinyatakan berapa besarnya kepemilikan oleh publik.

\section{Reputasi Kantor Akuntan Publik (KAP)}

Variabel ini diukur dengan menggunakan variabel dummy. Kategori perusahaan yang menggunakan jasa KAP yang berafiliasi dengan KAP Big 4 dibei nilai dummy 1 dan kategori perusahaan yang menggunakan jasa selain KAP yang berafiliasi dengan KAP Big 4 diberi nilai dummy 0 .

\section{Opini Auditor}

Opini Auditor dalam penelitian ini diukur dengan menggunakan variabel dummy. Kategori perusahaan yang mendapat unqualified opinion dari auditor diberi nilai dummy 1 dan kategori perusahaan yang mendapat opini selain unqualified opinion diberi nilai dummy 0 .

\section{METODE ANALISIS}

\section{Statistik Deskriptif}

Statistik deskriptif digunakan untuk mendeskripsikan dan memberikan gambaran tentang distribusi frekuensi variabel-variabel dalam penelitian ini, nilai maksimum, minimum, rata-rata (mean) dan standar deviasi. Berdasarkan data olahan SPSS, maka akan dapat diketahui nilai maksimum, nilai minimum, 
rata-rata (mean) dan standar deviasi dari setiap variabel. Sedangkan variable kompleksitas operasi perusahaan, reputasi KAP, dan opini auditor tidak diikutsertakan dalam perhitungan statistik deskriptif karena variabel-variabel tersebut memiliki skala nominal. Skala nominal merupakan skala pengukuran kategori atau kelompok (Ghozali, 2005, h. 3).

\section{Uji Hipotesis}

Pengujian terhadap hipotesis dalam penelitian ini dilakukan menggunakan regresi logistik (logistic regression). Karena menurut (Ghozali, 2005, h. 9) metode ini cocok digunakan untuk penelitian yang variabel dependennya bersifat kategorikal (nominal atau non metrik) dan variabel independennya kombinasi antara metrik dan non metrik seperti halnya dalam penelitian ini. Metode ini juga digunakan dalam penelitian sebelumnya oleh Hilmi dan Ali (2008). Model analisis logistic regression yang digunakan adalah sebagai berikut:

$L n(\mathrm{TL} / 1-\mathrm{TL})=\mathrm{a}+\mathrm{b} 1 \mathrm{ROA}+\mathrm{b} 2 \mathrm{CR}+\mathrm{b} 3 \mathrm{DER}+\mathrm{b} 4 \mathrm{TA}+\mathrm{b} 5$ OPERA + b6 KP +

$$
\mathrm{b} 7 \mathrm{KAP}+\mathrm{b} 8 \mathrm{OA}+\mathrm{e}
$$

Keterangan:

$\begin{array}{lll}\text { Ln (TL/1-TL) } & = & \text { Simbol yang menunjukkan probabilitas ketepatan } \\ & & \text { waktu penyampaian laporan keuangan tahunan } \\ \text { ROA } & = & \text { Profitabilitas (Return on Assets) } \\ \text { DER } & = & \text { Likuiditas (Current Ratio) } \\ \text { CR } & = & \text { Ukuran perusahaan (Total Asset) } \\ \text { TA } & = & \text { Kompleksitas Operasi Perusahaan } \\ \text { OPERA } & = & \text { Persentase kepemilikan publik (Shareholder's } \\ \text { KP } & & \text { Dispersion) } \\ \text { KAP } & = & \text { Reputasi KAP } \\ \text { OA } & = & \text { Opini Auditor } \\ \text { e } & = & \text { Error }\end{array}$

\section{Populasi dan Sampel}

Populasi yang digunakan dalam penelitian ini adalah seluruh perusahaan yang telah go public dan terdaftar di Bursa Efek Indonesia untuk periode waktu 2009, 2010, dan 2011. Teknik pengambilan sampel (sampling) yang digunakan adalah pemilihan sampel dengan pertimbangan purposive sampling (Indriantoro dan Supomo, 1999). Syarat yang digunakan untuk memilih sampel adalah perusahaan yang terdaftar di Bursa Efek Indonesia (BEI) secara berturut-turut untuk periode 2009, 2010, dan 2011; telah menerbitkan laporan keuangan tahunan untuk periode 2009-2011; dan memiliki data tanggal penyampaian laporan keuangan tahunan ke Bapepam untuk periode 2009 - 2011,

\section{PEMBAHASAN}

\section{Gambaran Umum Objek Penelitian dan Data Deskriptif}

Berdasarkan kriteria dalam pemilihan sampel, maka sampel perusahaan yang digunakan dalam penelitian ini adalah 296 perusahaan, sehingga jumlah sampel total dengan periode penelitian 3 tahun adalah 888 perusahaan. 
Tabel 1.

Proses Seleksi Sampel dengan Kriteria

\begin{tabular}{|r|l|c|c|}
\hline No & \multicolumn{1}{|c|}{ Kriteria } & \multicolumn{1}{|c|}{$\begin{array}{c}\text { Tidak } \\
\text { Memenuhi }\end{array}$} & Akumulasi \\
\hline 1 & $\begin{array}{l}\text { Perusahaan yang terdaftar di Bursa Efek Indonesia } \\
\text { BEI) secara berturut-turut untuk periode 2009, }\end{array}$ & - \\
\hline 2 & $\begin{array}{l}\text { Perusahaan tersebut telah menerbitkan laporan } \\
\text { keuangan tahunan untuk periode 2009, 2010, dan 2011 }\end{array}$ & 332 \\
\hline 3 & $\begin{array}{l}\text { Perusahaan yang memiliki data tanggal penyampaian } \\
\text { laporan keuangan tahunan ke Bapepam untuk periode } \\
\text { 2009, 2010 dan 2011 }\end{array}$ & 315 \\
\hline 4 & $\begin{array}{l}\text { Menampilkan data dan informasi yang digunakan } \\
\text { untuk faktor yang } \\
\text { mempengaruhi ketepatan waktu penyampaian laporan } \\
\text { keuangan untuk periode 2009, 2010, dan 2011 }\end{array}$ & 296 \\
\hline Jumlah Perusahaan Sampel & & 296 \\
\hline Tahun Pengamatan (tahun) & & 3 \\
\hline Jumlah sampel total selama periode penelitian & & 888 \\
\hline
\end{tabular}

Sumber : ICMD dan data diolah

Tabel 2.

Distribusi Perusahaan yang Tepat Waktu dan Tidak Tepat Waktu dalam Penyampaian Laporan Keuangan selama Periode Penelitian

\begin{tabular}{|l|c|c|c|c|c|c|}
\hline \multirow{2}{*}{ Kategori Perusahaan } & \multicolumn{5}{c|}{ Tahun Penelitian } \\
\cline { 2 - 7 } & \multicolumn{2}{|c|}{2009} & \multicolumn{2}{c|}{2010} & \multicolumn{2}{c|}{2011} \\
\cline { 2 - 7 } & Jumlah & $\%$ & Jumlah & $\%$ & Jumlah & $\%$ \\
\hline Perusahaan Tepat Waktu & 257 & $86.82 \%$ & 255 & $86.15 \%$ & 224 & $75.68 \%$ \\
\hline $\begin{array}{l}\text { Perusahaan Tidak Tepat } \\
\text { Waktu }\end{array}$ & 39 & $13.18 \%$ & 41 & $13.85 \%$ & 72 & $24.32 \%$ \\
\hline \multicolumn{1}{|c}{ Total } & $\mathbf{2 9 6}$ & $\mathbf{1 0 0 . 0 0 \%}$ & $\mathbf{2 9 6}$ & $\mathbf{1 0 0 . 0 0 \%}$ & $\mathbf{2 9 6}$ & $\mathbf{1 0 0 . 0 0 \%}$ \\
\hline
\end{tabular}

(Sumber: data sekunder, diolah) 
Tabel 3.

Distribusi Perusahaan yang Tepat Waktu dan Tidak Tepat Waktu dalam Penyampaian Laporan Keuangan Berdasarkan Jenis Industri

\begin{tabular}{|c|c|c|c|c|c|c|}
\hline & \multicolumn{2}{|c|}{ Tepat Waktu } & \multicolumn{2}{|c|}{ Tidak Tepat } & \multicolumn{2}{|c|}{ Total } \\
\hline & Jumlah & $\%$ & Jumlah & $\%$ & Jumlah & $\%$ \\
\hline Agriculture, Forestry and & 1 & $2.45 \%$ & 1 & $0.65 \%$ & 19 & 2.14 \\
\hline Animal Feed and Husbandry & 1 & $1.91 \%$ & 4 & $2.60 \%$ & 1 & 2.03 \\
\hline Mining and Mining Services & 2 & $3.27 \%$ & 6 & $3.90 \%$ & 30 & 3.38 \\
\hline Constructions & 9 & $1.23 \%$ & 3 & $1.95 \%$ & 12 & 1.35 \\
\hline Manufacturing & 320 & 43.60 & 5 & 35.71 & 37 & 42.23 \\
\hline Transportation Servi & 2 & $3.00 \%$ & 8 & $5.19 \%$ & 30 & 3.38 \\
\hline Telecommunication & 1 & $1.77 \%$ & 2 & $1.30 \%$ & 1 & 1.69 \\
\hline Whole Sale and Retail Trade & 3 & $5.18 \%$ & 7 & $4.55 \%$ & 45 & 5.07 \\
\hline $\begin{array}{l}\text { Banking, Credits Agencies } \\
\text { Other Than Bank, } \\
\text { Securities, Insurance and } \\
\text { Real Estate }\end{array}$ & 218 & $\begin{array}{c}29.70 \\
\%\end{array}$ & $\begin{array}{l}5 \\
3\end{array}$ & $\begin{array}{c}34.42 \\
\%\end{array}$ & $\begin{array}{c}27 \\
1\end{array}$ & $\begin{array}{c}30.52 \\
\%\end{array}$ \\
\hline Hotel and Travel Services & 1 & $1.77 \%$ & 5 & $3.25 \%$ & 18 & 2.03 \\
\hline $\begin{array}{l}\text { Holding and Other } \\
\text { Investment Companies }\end{array}$ & 8 & $1.09 \%$ & 3 & $1.95 \%$ & 11 & $\begin{array}{c}1.24 \\
\%\end{array}$ \\
\hline Others & 37 & $5.04 \%$ & 7 & $4.55 \%$ & 4 & 4.95 \\
\hline Total & 734 & 100.00 & 154 & 100.00 & 888 & 100.00 \\
\hline
\end{tabular}

(Sumber: data sekunder, diolah)

Statistik Deskriptif

Tabel 4.

Statistik Deskriptif Variabel-Variabel Penelitian

Descriptive Statistics

\begin{tabular}{|c|c|c|c|c|c|}
\hline & $\mathrm{N}$ & Minimum & Maximum & Mean & Std. Deviation \\
\hline ROA & 888 & -1.3030 & 1.4780 & .030708 & .1238004 \\
CR & 888 & -.30 & 455.00 & 3.7635 & 21.02740 \\
DER & 888 & -68.00 & 632.00 & 3.6364 & 25.58699 \\
Ln TA & 888 & 8.47300 & 19.69730 & 13.9090118 & 1.83553062 \\
KP & 888 & .0006 & 1.0000 & .276171 & .1793948 \\
Valid N & 888 & & & & \\
(listwise) & & & & & \\
\hline
\end{tabular}

(Sumber: Output SPSS 16.0)

Nilai minimum variable profitabilitas (ROA) adalah -1,3030 yaitu Bank Mutiara, Tbk. Pada tahun 2011 dan nilai maksimumnya adalah 1,4780 yaitu pada Eterindo Wahanatama, Tbk. Tahun 2011. Rata-rata variable profitabilitas adalah 0,030708 dengan standar deviasi 0,1238004 . Hal ini menunjukkan bahwa rata-rata keberhasilan perusahaan sampel dalam menghasilkan laba bersih adalah sebesar 
3,07 persen.

Nilai minimum variable likuiditas $(\mathrm{CR})$ adalah $-0,30$ yaitu pada Eratex Djaja, Tbk. Tahun 2011 dan nilai maksimumnya 455,00 yaitu oleh Bumi Teknokultura Unggul, Tbk. Tahun 2011. Rata-rata variable likuiditas adalah 3,7635 dengan standar deviasi 21,02740. Hal ini menunjukkan bahwa rata-rata kemampuan perusahaan dalam memenuhi kewajiban jangka pendeknya adalah sebesar 3,77, artinya : setiap Rp 1 kewajiban dijamin oleh Rp 3,77 aset lancar.

Nilai minimum variable leverage keuangan (DER) adalah sebesar $-68,00$ yaitu pada Schering Plough Indonesian, Tbk. Tahun 2009 dan nilai maksimumnya 632,00 yaitu oleh Pioneerindo Gourment International, Tbk. Tahun 2009. Ratarata variable leverage keuangan adalah 3,6364 dengan standar deviasi 25,58699.

Nilai minimum ukuran perusahaan (LnTA) adalah sebesar 8,47300 yaitu pada Rukun Raharja, Tbk. Tahun 2010 dan nilai maksimumnya 19,69730 yaitu oleh Bank Mandiri, Tbk pada tahun 2011. Hal ini menunjukkan bahwa logaritma natural (Ln) total asset yang dimiliki oleh perusahaan sampel adalah antara 8,473 sampai dengan 19,6973. Kemudian nilai rata-rata variable ukuran perusahaan (LnTA) adalah sebesar 13,9090118 dengan standar deviasi 1,83553062.

Nilai minimum variable kepemilikan public (KP) adalah 0,0006 yaitu pada Excelcomindo Pratama, Tbk. Tahun 2011 dan nilai maksimumnya adalah 1,00 yaitu pada JAPFA, Tbk. Tahun 2009. Rata-rata variable kepemilikan publik adalah 0,276171 dengan standar deviasi 0,1793948 . Hal ini berarti bahwa rata-rata kepemilikan publik pada perusahaan sampel adalah sebesar 27,61 persen.

Untuk gambaran umum sampel dengan variable kompleksitas operasi perusahaan, reputasi kantor akuntan public dan opini dari akuntan public dapat dilihat pada frequency table berikut :

Tabel 5.

Deskripsi data Kompleksitas Operasi Perusahaan

\begin{tabular}{|ll|r|r|r|c|}
\hline & & Frequency & Percen & Valid Percent & $\begin{array}{c}\text { Cumulative } \\
\text { Percent }\end{array}$ \\
\hline Valid & $\begin{array}{l}\text { Tidak ada anak } \\
\text { perusahaan }\end{array}$ & 271 & 30.5 & 30.5 & 30.5 \\
& & & & \\
& Ada anak \\
perusahaan & 617 & 69.5 & 69.5 & 100. \\
Total & 888 & 10 & 100.0 & 0 \\
& & 0. & & \\
\hline
\end{tabular}

(Sumber: Output SPSS 16.0)

Untuk perusahaan yang memiliki anak perusahaan diberi kode (1) sedangkan untuk perusahaan yang tidak memiliki anak perusahaan diberi kode (0). Berdasarkan table frekuensi yang dihasilkan, ada 271 observasi (30,5 persen) perusahaan yang tidak memiliki anak perusahaan sedangkan jumlah observasi perusahaan yang memiliki anak perusahaan sebanyak 617 observasi (69,5 persen). 
Tabel 6.

Deskripsi data Reputasi Kantor Akuntan Publik

\begin{tabular}{|l|r|r|r|r|}
\hline & Frequency & Percent & Valid Percent & $\begin{array}{c}\text { Cumulative } \\
\text { Percent }\end{array}$ \\
& & & & \\
\hline Valid KAP Non Big 4 & 522 & 58.8 & 58.8 & 58.8 \\
KAP Big 4 & 366 & 41.2 & 41.2 & 100.0 \\
Total & 888 & 10 & 100.0 & \\
\hline
\end{tabular}

(Sumber: Output SPSS 16.0)

Tabel 7.

Deskripsi data Opini Akuntan Publik

\begin{tabular}{|l|r|r|r|r|}
\hline & Frequenc & Percent & Valid Percent & $\begin{array}{c}\text { Cumulative } \\
\text { Percent }\end{array}$ \\
\hline Valid & $\begin{array}{l}\text { Selain } \\
\text { Unqualified } \\
\text { Opinion } \\
\begin{array}{l}\text { Unqualified } \\
\text { Opinion } \\
\text { Total }\end{array}\end{array} \quad 751$ & 15.4 & 15.4 & 15.4 \\
\hline
\end{tabular}

(Sumber: Output SPSS 16.0)

\section{Uji Hipotesis}

Menilai Kelayakan Model Regresi (Goodness of Fit)

Dari tampilan table Hosmer and Lemeshow Test pada table 8 ditunjukkan bahwa besarnya nilai statistic Hosmer and Lemeshow Goodness of Fit sebesar 5,333 dengan probabilitas signifikansi 0,721 dimana 0,721 >0,05 maka hipotesis nol tidak dapat ditolak (H0 diterima). Hal ini berarti model regresi yang dipergunakan dalam penelitian ini layak dipakai untuk analisis selanjutnya, karena tidak ada perbedaan yang nyata antara klasifikasi yang diprediksi dengan klasifikasi yang diamati.

Tabel 8.

Goodness of Fit Hosmer and Lemeshow Test

\begin{tabular}{|l|c|r|rr|}
\hline Step & Chi-square & df & \multicolumn{2}{|c|}{ Sig. } \\
\hline 1 & 5.333 & & 8 & \\
\hline
\end{tabular}

(Sumber: Output SPSS 16.0)

\section{Menilai Keseluruhan Model (Overall Model Fit)}

Pada table ditunjukkan uji kelayakan dengan memperhatikan angka pada awal -2 Log Likelihood (LL) block Number =0, sebesar 819,211 dan angka pada 2 Log Likelihood (LL) block Number = 1, sebesar 773,095. Hal ini menunjukkan terjadinya penurunan nilai -2 Log Likelihood di block 0 dan block 1 sebesar $819,211-773,095=46,126$ dan mempunyai signifikansi $0,000<0,05$ yang signifikan. Artinya bahwa secara keseluruhan model regresi logistic yang digunakan merupakan model yang baik. 
Tabel 9.

Overall Model Fit

\begin{tabular}{|l|l|}
\hline Iteration & -2 Log likelihood \\
\hline Step 0 & 819,211 \\
\hline Step 1 & 773,095 \\
\hline
\end{tabular}

(Sumber: Output SPSS 16.0)

Menguji Koefisien Regresi

Dari pengujian persamaan regresi logistik tersebut, maka diperoleh model regresi logistik sebagai berikut :

$\operatorname{Ln}(\mathrm{TL} / 1-\mathrm{TL})=-4,392-3,124 \mathrm{ROA}+0,006 \mathrm{CR}+0,003 \mathrm{DER}+$

$0,170 \mathrm{TA}+0,450 \mathrm{OPERA}+1,005 \mathrm{KP}-0,458 \mathrm{KAP}+0,020 \mathrm{OA}+\mathrm{e}$

Tabel 10.

Tabel Uji Koefisien Regresi

\begin{tabular}{|ll|r|r|l|}
\hline & & \multicolumn{1}{|c|}{ B } & \multicolumn{1}{c|}{ Sig. } & \multicolumn{1}{|c|}{ Hasil } \\
\hline Step & Profitabilitas & -3.124 & .000 & Signifikan \\
$1(\mathrm{a})$ & & & & \\
& Likuiditas & .006 & .077 & Tidak Signifikan \\
& Leverage Keuangan & .003 & .341 & Tidak Signifikan \\
& Ukuran Perusahaan & .170 & .002 & Signifikan \\
& Kompleksitas Operasi & .450 & .045 & Signifikan \\
Perusahaan & & & \\
Kepemilikan Publik & 1.005 & .046 & Signifikan \\
Reputasi KAP & -.458 & .034 & Signifikan \\
Opini Auditor & .020 & .935 & Tidak Signifikan \\
Constant & -4.392 & .000 & \\
\hline
\end{tabular}

(Sumber: Output SPSS 16.0)

\section{Pengujian Hipotesis}

H1: Profitabilitas berpengaruh terhadap ketepatan waktu penyampaian laporan keuangan.

Variabel profitabilitas menunjukkan nilai koefisien regresi sebesar $-3,124$ dengan probabilitas variable sebesar 0,000 di bawah signifikansi 5\%. Hal ini berarti bahwa $\mathrm{H} 1$ diterima.

$\mathrm{H} 2$ : Likuiditas berpengaruh terhadap ketepatan waktu penyampaian laporan keuangan.

Variabel likuiditas menunjukkan nilai koefisien regresi sebesar 0,006 dengan probabilitas variabel sebesar 0,77 di atas signifikansi 5\%. Hal ini mengandung arti bahwa $\mathrm{H} 2$ ditolak.

H3: Leverage keuangan berpengaruh terhadap ketepatan waktu penyampaian laporan keuangan.

Variabel leverage keuangan menunjukkan nilai koefisien regresi sebesar 0,003 dengan probabilitas variable sebesar 0,341 di atas signifikasi 5\%. Hal ini berarti bahwa $\mathrm{H} 3$ ditolak.

H4: Ukuran perusahaan berpengaruh terhadap ketepatan waktu penyampaian laporan keuangan. 
Variabel ukuran perusahaan menunjukkan nilai koefisien regresi sebesar 0,170 dengan probabilitas variable sebesar 0,002 di bawah signifikansi 5\%. Hal ini berarti bahwa $\mathrm{H} 4$ diterima.

H5: Kompleksitas operasi perusahaan berpengaruh terhadap ketepatan waktu penyampaian laporan keuangan.

Variabel kompleksitas operasi perusahaan menunjukkan nilai koefisien regresi sebesar 0,450 dengan probabilitas variable sebesar 0,045 di bawah signifikansi $5 \%$. Hal ini berarti bahwa $\mathrm{H} 5$ diterima.

H6: Kepemilikan public berpengaruh terhadap ketepatan waktu penyampaian laporan keuangan.

Variabel kepemilikan publik menunjukkan nilai koefisien regresi sebesar 1,005 dengan probabilitas variable sebesar 0,046 di bawah signifikansi 5\%. Hal ini berarti bahwa H6 diterima.

H7: Reputasi kantor akuntan public (KAP) berpengaruh terhadap ketepatan waktu penyampaian laporan keuangan.

Variabel reputasi kantor akuntan public menunjukkan nilai koefisien regresi sebesar $-0,458$ dengan probabilitas variable sebesar 0,034 di bawah signifikansi 5\%. Hal ini berarti bahwa $\mathrm{H} 7$ diterima.

H8: Opini auditor berpengaruh terhadap ketepatan waktu penyampaian laporan keuangan.

Variabel opini auditor menunjukkan nilai koefisien regresi sebesar 0,020 dengan probabilitas variable sebesar 0,935 di atas signifikansi 5\%. Hal ini berarti bahwa $\mathrm{H} 8$ ditolak.

\section{PENUTUP}

\section{Kesimpulan}

1. Profitabilitas berpengaruh terhadap ketepatan waktu penyampaian laporan keuangan dengan arah keofisien regresi dalam penelitian ini bertanda negatif, yang berarti bahwa semakin tinggi tingkat profitabilitas secara signifikan berpengaruh terhadap semakin rendahnya tingkat ketepatan waktu penyampaian laporan keuangan.

2. Likuiditas perusahaan tidak berpengaruh terhadap ketepatan waktu penyampaian laporan keuangan. Tingkat likuiditas suatu perusahaan tidak mempengaruhi perusahaan untuk menyampaikan laporan keuangannya dengan tepat waktu atau tidak tepat waktu.

3. Leverage keuangan suatu perusahaan tidak berpengaruh terhadap ketepatan waktu penyampaian laporan keuangan. Tinggi rendahnya tingkat leverage keuangan suatu perusahaan tidak mempengaruhi perusahaan untuk menyampaikan laporan keuangannya dengan tepat waktu atau tidak tepat waktu.

4. Ukuran perusahaan berpengaruh terhadap ketepatan waktu penyampaian laporan keuangan. Semakin besar ukuran perusahaan, semakin banyak memiliki sumber daya, lebih banyak staf akuntansi dan sistem informasi yang canggih serta memiliki sistem pengendalian intern yang kuat sehingga akan semakin cepat dalam penyelesaian laporan keuangan 
5. Kompleksitas operasi perusahaan berpengaruh terhadap ketepatan waktu penyampaian laporan keuangan. Tingkat kompleksitas operasi perusahaan yang tergantung pada jumlah anak perusahaannya cenderung mempengaruhi waktu auditor untuk menyelesaikan tugas auditnya, sehingga berpengaruh terhadap ketepatan waktu penyampaian laporan keuangan oleh perusahaan.

6. Kepemilikan publik berpengaruh terhadap ketepatan waktu penyampaian laporan keuangan. Dengan adanya konsentrasi kepemilikan public, maka pihak manajemen akan lebih mendapat tekanan dari pihak luar perusahaan atau shareholder untuk lebih tepat waktu dalam penyampaian laporan keuangan tahunan perusahaan.

7. Reputasi kantor akuntan publik (KAP) berpengaruh terhadap ketepatan waktu penyampaian laporan keuangan. Perusahaan yang memakai jasa kantor akuntan publik (KAP) besar cenderung tepat waktu dalam menyampaikan laporan keuangannya.

8. Opini auditor tidak berpengaruh terhadap ketepatan waktu penyampaian laporan keuangan. Perolehan unqualified opinion ataupun selain unqualified opinion oleh perusahaan tidak mempengaruhi ketepatan waktu penyampaian laporan keuangan perusahaan tersebut.

\section{Saran}

Saran yang dajukan untuk penelitian selanjutnya yaitu :

1. Memperpanjang periode penelitian sehingga dapat melihat kecenderungan yang terjadi dalam jangka panjang sehingga akan menggambarkan kondisi yang sesungguhnya terjadi.

2. Proksi yang digunakan untuk variabel independen tidak hanya satu proksi saja. Agar hasil yang diperoleh dapat lebih baik dan lebih luas lagi daripada penelitian ini.

\section{DAFTAR PUSTAKA}

Afriyeni, A., \& Marlius, D. (2018). Analisis Pengaruh Informasi Prospektus Perusahaan Terhadap Initial Return Saham Pada Pasar Perdana Di Bursa Efek Indonesia. https://doi.org/10.31219/osf.io/kt6c4

Dogan, Mustafa, Ender Coskun and Orhan Celik. 2007. "Is Timing of Financial Reporting Related to Firm Performance? An Examination on Ise Listed Companies". International Research Journal of Finance and Economics. Issue 12. EuroJournals Publishing, Inc.

Hilmi, Utari dan Syaiful Ali. 2008. "Analisis Faktor-Faktor Yang Memepengaruhi Ketepatan Waktu Penyampaian Laporan Keuangan (Studi Empiris pada Perusahaan-perusahaan yang Terdaftar di BEJ)". Simposium Nasional Akuntansi XI Ikatan Akuntan Indonesia.

Jensen, M. C. dan Meckling, W. H. 1976. "Theory of Firm: Managerial Behaviour, Agency Costs and Ownership Structure". Journal of Financial Economics.3. Pp. 305-360. 
Kadir, Abdul. 2008. Faktor-Faktor yang Berpengaruh Terhadap Ketepatan Waktu Pelaporan Keuangan. Tesis Tidak Dipublikasikan. Fakultas Ekonomi Universitas Diponegoro.

Kuncoro, Mudrajad. 2001. Metode Kuantitatif Teori dan Aplikasi untuk Bisnis dan Ekonomi. Edisi Pertama. Cetakan Pertama. Yogyakarta: UPP AMP YKPN.

Oktorina, Megawati dan Michell Suharli. 2005. "Studi Empiris Terhadap Faktor Penentu Kepatuhan Ketepatan Waktu Pelaporan Keuangan". Jurnal Ekonomi dan Bisnis. Vol. 5. No.2. h. 119-132.

Owusu-Ansah, Stephen. 2000. "Timeliness of Corporate Financial Reporting in Emerging Capital Market: Empirical Evidence from The Zimbabwe Stock Exchange”. Journal Accounting and Business Research. Vol.30. No.3.

Putri, A. D., \& Mayliza, R. (2019). Pengaruh Good Corporate Governance Dan Leverage Terhadap Kinerja Keuangan Pada Perbankan Yang Terdaftar Di BEI. https://doi.org/10.31219/osf.io/b8he7

Saleh, Rachmad dan Susilowati. 2004. "Studi Empiris Ketepatan Waktu Pelaporan Keuangan Perusahaan Manufaktur di Bursa Efek Jakarta”. Jurnal Bisnis Strategi. Vol.13. h. 67-80.

Sulistyanto, H. Sri. 2008. Manajemen Laba: Teori dan Model Empiris. Jakarta: PT Grasindo

Supriati dan Yuliasri Rolinda. 2007. "Analisis Faktor-Faktor yang Mempengaruhi Audit Delay (Studi Empiris pada Perusahaan Manufaktur dan Finansial di Indonesia)". Jurnal Ekonomi Bisnis dan Akuntansi Ventura. Vol. 10. No. 7. h. 109-126.

Ukago, Kristianus. 2004. Faktor-Faktor yang Berpengaruh Terhadap Ketepatan Waktu Pelaporan Keuangan Bukti Empiris Emiten di Bursa Efek Jakarta. Tesis Tidak Dipublikasikan. Fakultas Ekonomi Universitas Diponegoro.

www.bapepam.go.id

www.idx.co.id 